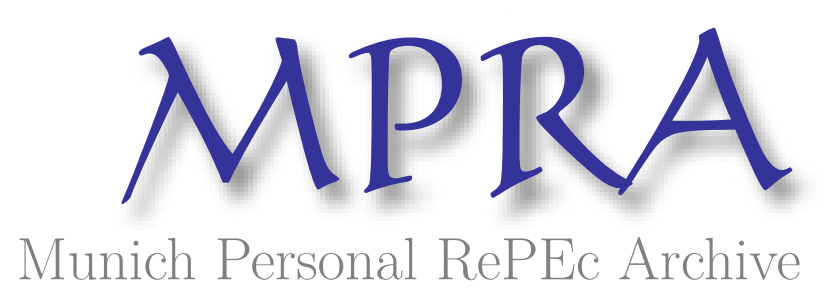

\title{
German Electricity Reserve Markets
}

\author{
Riedel, Stefan and Weigt, Hannes
}

2007

Online at https://mpra.ub.uni-muenchen.de/65664/

MPRA Paper No. 65664, posted 19 Jul 2015 09:38 UTC 


\title{
Electricity Markets Working Papers
}

\author{
WP-EM-20
}

\section{German Electricity Reserve Markets}

\author{
Stefan Riedel and Hannes Weigt
}

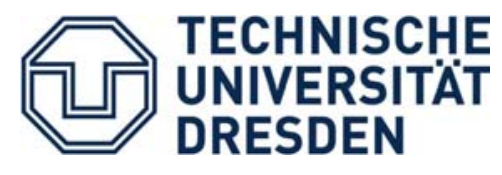

Dresden University of Technology
Chair for Energy Economics and Public Sector Management 


\title{
German Electricity Reserve Markets
}

\author{
Stefan Riedel ${ }^{1}$ and Hannes Weigt
}

Corresponding author:

Hannes Weigt

Dresden University of Technology

Department of Business Management and Economics

Chair of Energy Economics

D - 01069 Dresden

Germany

Phone: +49-(0)351-463-39764

Fax: $\quad+49-(0) 351-463-39763$

Hannes.weigt@tu-dresden.de

\section{Abstract:}

This paper analyzes the functioning of the markets for electricity reserves in Germany. We provide an overview of the technical requirements and the market design and structure of the primary, secondary and tertiary reserve markets, and then look at developments following the introduction of market-based reserve management. We assess the dependence of the minute reserve market by conducting a correlation analysis. The results indicate an increasing correlation among Germany's four local markets as well as a relationship to wholesale market outcomes. We test the competitiveness of the reserve market by estimating the average income a peak load supplier can obtain by bidding on the reserve market.

Key words: electricity, Germany, reserve market

JEL-code: $\quad$ L94

\footnotetext{
${ }^{1}$ This paper summarizes the diploma thesis by Stefan Riedel, "Power Reserve Markets - A Theoretical Discussion and Empirical Analysis of the German Power Reserve Markets."
} 


\section{Introduction}

The liberalization of the Continental European power markets which began in 1996 resulted in the breakup of the region's vertically integrated utilities and the development of new power markets. A spot market and a forward market emerged from the traditional direct trading agreements, and markets for futures, OTC options, exchange options, swaps etc. appeared. Expanded market participation increased market liquidity, giving rise to potential competition.

Whereas both spot and forward markets and their related products have been extensively analyzed and discussed, reserve markets have not received the same attention. In Germany these markets now have a daily volume of more than $7 \mathrm{GW}$, corresponding to almost $9 \%$ of the available capacity. In 2006, the procurement costs in the different power reserve markets totaled approximately $€ 800$ million.

This paper will discuss Germany's power reserve markets in detail. The underlying market design and rules will be presented, followed by an evaluation of market competitiveness. The paper is structured as follows: Chapter 2 gives an overview of the general organization and legal framework of Germany's electricity markets and their distinctive characteristics. Chapter 3 provides the technical details and requirements of the primary, secondary and tertiary control types and specifies the functioning of the different power reserve markets. Chapter 4 presents a correlation analysis between the prices for incremental minute reserve power on the different German markets and the day-ahead peak load hour prices at the European Energy Exchange (EEX). The costs of a gas turbine providing incremental minute reserve power are considered, and inferences for a fair price level in the relevant markets for this type of control are drawn. Chapter 5 summarizes the findings and offers a suggestion for future research.

\section{Market overview}

\subsection{Electricity market structure}

Electricity markets can generally be divided into wholesale, retail and balancing markets (Moselle et al., 2006). In the wholesale market, generators and importers act on the supply side while wholesale traders as well as key accounts or utilities act on the demand site. The retail market comprises (local) utilities on the supply side and smaller industrial customers and residential consumers on the demand side. Balancing markets (power reserve markets) "balance" the real-time deviations between supply and demand as wholesale markets settle before actual delivery to the end-users.

The wholesale markets can be further subdivided in short-term and long-term or forward markets. Contracts with an exercise date of more than one month ahead are attributed to the forward market. The prices in the forward market correlate to the prices in the spot market prices because they represent today's expectation of the spot market price at the exercise date of the contract.

The wholesale electricity market distinguishes among bilateral contracts, over the counter (OTC) transactions and contracts traded at power exchanges. Bilateral contracts and OTC transactions allow 
customized products Contracts traded at power exchanges have no counter party risk, transparent prices and volumes, offer standardized products, and guarantee the anonymity of both parties at all times. The high standardized, exchange traded forward contracts are called 'futures', and are usually settled financially.

In Germany, the wholesale market is divided into an OTC segment and the standardized exchange. The OTC market amounts to almost 1.900 TWh (RWE Trading GmbH, 2007) and has the largest share of wholesale trade in Germany. The power exchange is the European Energy Exchange (EEX) in Leipzig, which allows both spot and forward trading with a range of standardized products. In 2006, the EEX registered a trading volume of 1.044 TWh on the derivatives market (compared to 517 TWh in 2005) and a volume of 89 TWh on the spot market (cf. EEX AG, 2007). Since 25 September 2006, the EEX also operates an intra-day market. The trading volume between this date and 31 December 2006 totaled more than $136 \mathrm{GWh}$ which corresponds to nearly $1.400 \mathrm{MWh}$ daily.

In European electricity markets, each country's Transmission System Operators (TSOs) are responsible for the procurement of power reserves. Since 2002, German TSOs have procured reserves via competitive bidding in specialized markets. Since the country's grid operates within the network of the Union for the Co-ordination of Transmission of Electricity (UCTE), the German TSOs must procure three types of reserve power: primary, secondary and tertiary control.

\subsection{The EU's legal framework}

European electricity markets faced large-scale changes throughout the last decade. In Germany, the EU directive 96/92/EC (European Parliament/European Council, 1996) was incorporated in German law in April 1998 (Energy Industry Act, or EnWG). To expedite liberalization, the European Parliament/European Council amended its 1996 directive by issuing the "acceleration directive" 2003/54/EC (European Parliament/European Council, 2003). Germany incorporated the June 2003 directive on July 7, 2005.

However, the legal framework presented a conundrum. On one hand, the TSOs and Distribution System Operators (DSOs) were committed to guarantee non-discriminatory grid access and grid use to third parties. On the other, all power supply companies with more than 100, 000 customers were compelled to develop functional, legal and account unbundling. The conundrum has not yet been resolved: transmission and distribution operations continue to exist as a natural monopoly, but the former supply areas are now control areas. ${ }^{2}$

In the course of unbundling, four German transmission operators came into existence: EnBW Transportnetze AG, E.ON Netz GmbH, RWE Transportnetz Strom GmbH and Vattenfall Europe Transmission GmbH; all are members of the UCTE, The UCTE has published several rules concerning load-frequency control, or LFC (UCTE, 2004a,b), that define the technical framework for the duties and responsibilities of the TSOs. Within the scope of the German TSO cooperation

\footnotetext{
2. Unbundling of generation and transmission companies is under consideration. In January 2007, the president of the European commission, José Manuel Barroso, signaled that utilities could be obliged to sell their grids (both electricity and gas) to a third party.
} 
(Verband Deutscher Netzbetreiber, VDN), the German TSOs have adopted Transmission Code 2003 (VDN, 2003c), which includes the rules and regulations as well as the technical requirements for the provision of balancing and reserve power. The major tasks described in this code are the system services:

- Frequency Stability: TSOs are obliged to maintain enough balancing and reserve power (primary, secondary and minute reserve power) within the scope of their responsibilities to ensure reliable system operations. The transmission system must provide enough transmission capacity and infrastructure for both the transmission of the projected maximum load and the transmission of reserve power. The TSOs procure control power via bidding on competitive terms and conditions, and the bidding results are published. The ability of connection users/bidders to satisfy the UCTE's minimum requirements must be proven through a prequalification procedure (cf. VDN, 2003a,b, 2006). Finally, the framework agreements concerning the terms and conditions for providing control power between the TSOs and the connection users/bidders are settled.

- Voltage Stability: Each TSO must ensure voltage stability in its control area, which involves the power grid (transmission and distribution networks), generating units, power stations, consumers, and the boundary areas of the adjacent network. To ensure balanced reactive power management, the TSOs must maintain facilities for reactive compensation or provide them by contractual arrangements (for more details see Schwab (2006) or VDN (2003c)).

- Restoration of Supply: To prepare for large-scale failure, the TSOs are obliged to draw up appropriate plans for preventive and operational measures in conjunction with adjacent TSOs or with subordinated DSOs and power station operators. TSOs must also have black-start capability and the capability of isolated operations to provide supply restoration.

- System Management: The rubric "System Management" spans several tasks, such as the assurance of network security, the performance of voltage/reactive power and power/frequency control operations, or metering and pricing between TSOs and connection users. Moreover, it includes the operational implementation of the generation schedules for power stations in accordance with the requirements for secondary control power, the activation of minute reserve and, if necessary, emergency reserve. This latter task requires congestion forecasting, congestion management, load forecasting for the control area, observation of the instantaneous commitment of the power stations, and the coordination or utilization of ancillary services.

Schwab (2006) has subdivided the tasks of the TSOs into network management and system balancing (Table 1). In this paper, only the procurement and activation of power reserves and LFC will be discussed; network management or other system balancing services (balancing wind power generation, bottleneck management by re-dispatching, etc.) are not analyzed. 


\begin{tabular}{|l|l|}
\hline \multicolumn{1}{|c|}{ Network Management } & \multicolumn{1}{|c|}{ System Balancing } \\
\hline - Monitoring and control & - Scheduling \\
- Ensuring the n-1 reliability & - Procurement and activation of power \\
- Planning of disconnection & \multicolumn{2}{|c|}{ reserves } \\
- Bottleneck management by changing the? & - LFC \\
- Voltage and reactive power optimization & - Balancing wind power generation \\
- Survey and removal of disturbances & - Bottleneck management by re-dispatch \\
- Network reconstruction & - Planning of system services \\
\hline
\end{tabular}

The industry's merger and acquisition activity brought the Federal Cartel Office (FCO) into the picture. In the merger of RWE AG and VEW, the FCO asserted that both were the sole consumers in the market for procuring minute reserve power (FCO, 2000a), but since minute reserve power was procured in either their own power plants or power plants bound by contract, they were the sole suppliers as well. In the downstream market, the consumers of minute reserve power (usually the balancing group managers) faced only RWE AG and VEW as suppliers (the same applied for the markets for primary and secondary control power). According to the FCO, ineffective pricing of balancing and reserve power sent inefficient price signals to market players when compared to competitive organized markets.

Therefore, the FCO issued special requirements in connection with this particular merger. RWE AG, the new company, was obliged to combine the two control areas of RWE AG and VEW to lessen the overall demand of power reserves. The FCO also compelled it to procure needed power reserves through competitive bidding procedures (imbalance auctions). Beginning in October 2000, RWE AG was obligated to announce an open pre-qualification procedure (PQ), and the technical requirements for participation were based upon the rules of the UCTE (UCTE, 2004b) as well as the common rules of the German grid (VDN, 2003c). The geographical location of the bidder should not be taken into account.

As of February 2001, the duration of the bidding periods for primary and secondary control power was six months, with an even shorter period projected for the future. Currently, the bidding periods for primary and secondary control power are still six months. Also in February 2001, minute reserve power was tendered for three months; later bidding periods were expected to span two months and one month. Beginning in August 2001, minute reserve power was tendered day-ahead for each hour of the following day and procured at the respective market price by RWE AG. The bidding results were published anonymously. The FCO justified mandating a short-term day-ahead auction of minute reserve power on the basis that extended bidding periods would counteract the natural short-term character of these trading operations, and distorted price signals would influence competition. The FCO argued that only short-term bidding would enable efficient competition because more power plants would be able to provide their short-run excess capacities. RWE AG was also required to 
reorganize its billing procedures for primary and secondary control for net customers so that pricing and bidding results corresponded, and charges to the balancing group managers were changed into a "pure" energy rate bill.

During the three other mergers and acquisitions, the FCO successfully commenced proceedings concerning the misuse of market power against E.ON AG, EnBW AG and Vattenfall Europe AG. As of December 2001, E.ON now procures power reserves through competitive bidding, and as of June 2002, minute reserve power is tendered day-ahead. EnBW instituted bidding on August 2002 (day ahead minute reserve power since February 2003). VET instituted bidding on September 2002 (dayahead minute reserve since 1 April 2003).

However, FCO's goal of stimulating competition on the supply side (through public bidding, shortened bidding periods and more transparency), thus generating positive effects for balancing groups and customers, has not been fully achieved. Considering the fact that today there are between 4 and 18 actors on the different power reserve markets, it is not appropriate to speak of true competition. The divergence of spot prices and balancing charges is still excessive, and transparency and open market access are not yet realized. Regulatory inadequacy can be blamed as one reason for these market failures.

On July 13, 2005, the former 'Regulatory Authority for Telecommunications and Postal Services' (RegTP) was renamed the 'Federal Network Agency for Electricity, Gas, Telecommunications, Postal Services and Railways' (FNA). FNA's two major tasks are the surveillance of misuse (ex post regulation) and the authorization of future network fee increases (ex ante regulation).It enacted board decision BK6-06-012 on August 29, 2006 (FNA, 2006b) to re-regulate the procurement of minute reserve power. One day later, it issued a list of key points to consider for primary control and secondary control auctions in the future (FNA, 2006c,d).

\section{Technical Specifications and Development}

In the UCTE, LFC consists of three stages: primary, secondary and tertiary control. The latter is also called time reserve and can be subdivided into minute reserve ( $<60 \mathrm{~min})$ and hour reserve ( $>60 \mathrm{~min})$. The procurement of hour reserve is usually the responsibility of generators or the respective balancing group managers. ${ }^{3}$ LFC functionality is depicted in Figure 1.

\footnotetext{
${ }^{3}$ This paper does not consider hour reserve which is used to hedge a generator's supply contracts and thus is not part of the control process.
} 
Figure 1: Functionality of the Load-Frequency Control. (Following BET Aachen, 2006)

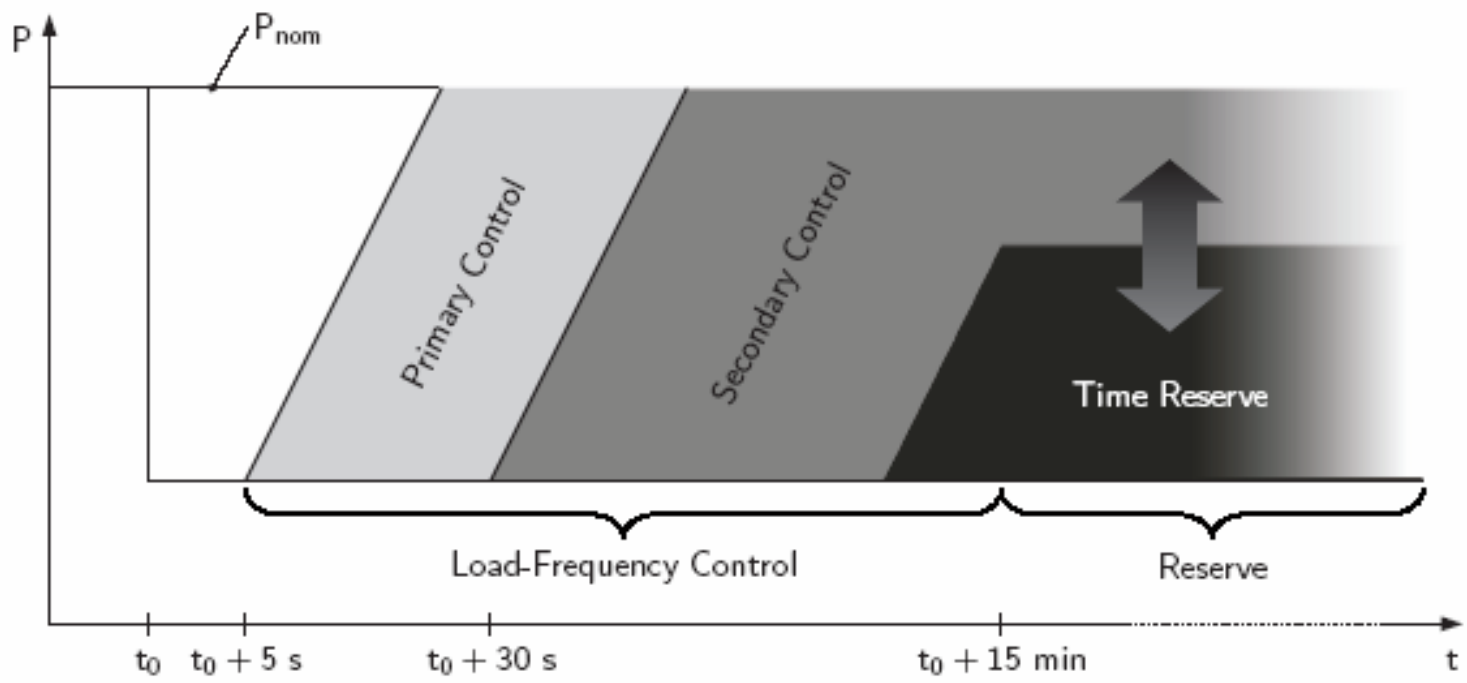

\subsection{Primary Control}

In any electric system, "active" power is generated and used at the same time - a delicate balancing act for the production, transmission, distribution and consumption of a commodity that cannot be stored. Disturbances in this balance will cause system frequency to deviate from its set-point value of $50 \mathrm{~Hz}{ }^{4}$ When there is a deviation, all primary regulating units react within a few seconds with an increased power output. Therefore, they are required to reserve a small amount of their "nominal" power (approximately 4-5\%). The nominal power reserved (also known as primary control reserve), is supported by the passive share of the network-frequency-dependent load, ("self-regulation effect"); when demand increases, and thus frequency decreases, load decreases in a similar fashion (it is assumed that a load decrease of $1 \%$ occurs in case of a frequency drop of $1 \mathrm{~Hz}$ ). Activating primary control (primary control action) allows a balance to be re-established at a system frequency other than the frequency set-point value of $50 \mathrm{~Hz}$. This is called a quasi-steady-state frequency deviation $\Delta \mathrm{f}$ (Figure 2). After a short period (normally five minutes), secondary control action restores the system frequency to the set-point value of $50 \mathrm{~Hz}$ and sets primary control free.

\footnotetext{
${ }^{4}$ Frequency is a measure of the rotation speed of the synchronized generators; if total demand increases, the system frequency and thus the speed of generators decreases, and vice versa.
} 
Figure 2: Quasi-Steady-State Deviation after Primary Control Action. (Following Poll, 2002; UCTE, 2004a)

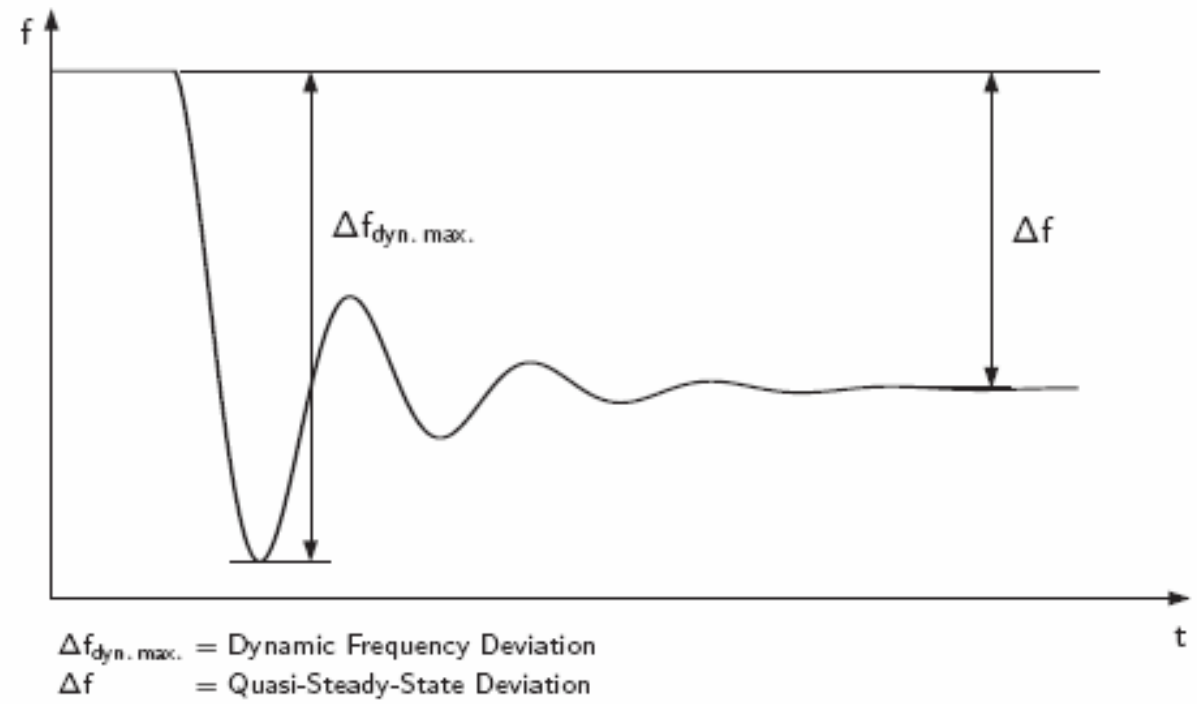

The frequency deviation is influenced by the total inertia in the system and the speed of primary control action. The magnitude of the dynamic frequency deviation $\Delta \mathrm{f}_{\text {dyn. max }}$. is governed by:

- The amplitude and developing over time of the disturbance affecting the balance between power output and consumption

- The kinetic energy of rotating machines in the system

- The number of generators subject to primary control, the primary control reserve and its distribution among these generators

- The dynamic characteristics of the machines and controllers

- The dynamic characteristics of loads, particularly their self-regulating effect.

The magnitude of the quasi-steady-state frequency deviation $\Delta \mathrm{f}$ is governed by:

- The amplitude of the disturbance and the network power frequency characteristic, which is influenced mainly by the droop of all generators subject to primary control

- The sensitivity of consumption to variations in system frequency.

In undisturbed conditions, system frequency in the UCTE must be maintained within strict limits to ensure the full, rapid commitment of control facilities in response to a disturbance:

- Calling Up of Primary Control: In undisturbed operation at or near the nominal frequency (i.e., the deviation does not exceed $\pm 20 \mathrm{mHz}$ ), primary control is not called up, but primary control activates automatically whenever the threshold is exceeded.

- Maximum Quasi-Steady-State Frequency Deviation: The maximum quasi-steady-state frequency deviation must not exceed $\pm 180 \mathrm{mHz}$. 
- Minimum Instantaneous Frequency: The instantaneous frequency must not fall below 49.2 $\mathrm{Hz}$ in response to a shortfall in generation capacity equal to the maximum power deviation (3.000 MW) to be handled.

- Load-Shedding Frequency Criterion: If the system frequency drops below $49.0 \mathrm{~Hz}$, loadshedding occurs automatically or manually. ${ }^{5}$

- Maximum Instantaneous Frequency: The instantaneous frequency must not exceed $50.8 \mathrm{~Hz}$ in response to a loss of load or interruption of power interchanges equal to or less than 3.000 MW within Zone 1 of the UCTE grid.

The provision of primary control power to any control area is shared mutually by all UCTE-member TSOs and is allocated based on their annual production volumes. ${ }^{6}$ For the first synchronous zone (Zone 1), $3.000 \mathrm{MW}$ of primary control capacity are procured. The UCTE argues that this amount hedges against the simultaneous trip of two generation units each with $1.500 \mathrm{MW}$ ( $\mathrm{n}-2$ criterion), or against the loss of a line section or busbar. Considering the reference incident of $3.000 \mathrm{MW}$ (loss of generation or load), the primary control reserve of each control area must be fully activated within 15 seconds in response to disturbances $\Delta \mathrm{P}$ of less than $1.500 \mathrm{MW}$, and within a linear time limit of 15 to 30 seconds in response to a $\Delta \mathrm{P}$ of 1.500 to $3.000 \mathrm{MW}$ respectively. The primary control reserve must be available for at least 15 minutes. The time availability is $100 \%$ during the entire bidding period. The accuracy of local frequency measurements used by the primary controllers must be equal to or exceed $10 \mathrm{mHz}$ (in Germany, the provided control range of each technical unit must span at least $\pm 2 \%$ and a minimum $\pm 2 \mathrm{MW}$ of its nominal power). The minimum bid size of primary control power within both the EnBW and the VET control area is quoted as $\pm 10 \mathrm{MW}$; E.ON and RWE give no particulars on their Web sites.

\subsection{Secondary Control}

Because an imbalance in one control area of the UCTE will also cause power exchanges between other adjacent control areas to deviate from the scheduled values, secondary control acts to maintain or to restore both the system frequency to its set-point value and the power interchanges with adjacent control areas to their programmed scheduled values. Secondary control ensures that the full reserve of activated primary control power is again made available. As a matter of course, it must not impair the action of primary control. Its actions occur simultaneously and continually in response to both the minor deviations and major discrepancies between generation and consumption that are associated with the tripping of a generating unit or a network disconnection. To fulfill these requirements in parallel, secondary control is operated by the network characteristic method. According to this

\footnotetext{
${ }^{5}$ The TSOs have designed detailed step-plans for load-shedding with the possibility to perform shedding of pumping units at other frequency values - with the lowest value of $47.5 \mathrm{~Hz}$ and the need of intermediate progressive stages (cf. UCTE, 2004b). Load-shedding can also encompass a percentage of consumer load as a last resort.

${ }^{6}$ Since December 1, 2006, 661 MW of primary control power - both incremental and decremental - are provided within the four German control areas.
} 
method, each control area is equipped with one secondary controller to minimize the area control error in real-time.

In contrast to the primary control process, secondary control action is only undertaken by the control area affected by the power imbalance. Parameters for the secondary controllers of all control areas are established such that - ideally - only the controller in the affected area will respond to the disturbance and initiate the commitment of secondary control power. Unlike primary control, secondary control operates for several minutes. This behavior over time is associated with the proportional-integral characteristic of the secondary controller. Secondary control makes use of both measurements of the system frequency and of the active power flows on the control area's tie-lines. Moreover, the secondary control process requires the secondary controller to compute the power set-point values of the selected generation sets and later transmit the values to them. This automatic simultaneous central control is known as automatic generation control and exists only in the UCTE.

When consumption exceeds generation permanently, balance must be immediately restored by the use of standby supplies, contractual load variation or load-shedding. At all times, sufficient transmission capacity for the accommodation of control capacity and standby supplies must be maintained, and especially when providing secondary control power from outside the control area. Usually there are no bottlenecks among the four German control areas, but many market participants argue that the existing transmission capacity should be used for power trading instead of transmitting control power.

To utilize the output of a generator for secondary control, its rate of change must meet specific values. The rate of change for oil- or gas-fired units is in the range of $8 \%$ per minute. Reservoir power stations, such as pumped storage plants, must have rates between 1.5 and $2.5 \%$ per second, whereas for hard coal- and lignite-fired plants, rates from 2 to $4 \%$ per minute and 1 to $2 \%$ per minute respectively are sufficient. The maximum rate of change for nuclear plants is approximately 1 to $5 \%$ per minute. The size of the secondary control reserve depends on the size of typical load variations, schedule changes and generating units. In principle, each TSO can define the amount of procured secondary control reserve (SCR). According to the UCTE, the minimum reserve can be calculated with the following empirical formula without distinguishing between incremental and decremental reserves:

$$
R=\sqrt{a L_{\max }-b^{2}}-b
$$

with $\quad \mathrm{R}=$ recommendation for secondary control reserve [MW]

$\mathrm{L}_{\max }=$ maximum anticipated load for the control area $[\mathrm{MW}]$.

The parameters $a$ and $b$ are established empirically. For the UCTE the values are $a=10 \mathrm{MW}$ and $b=$ 150 MW. The respective values of $R$ for the German TSOs are given in Table 2 indicating an oversupply of reserved capacity. 
Table 2: Recommended Minimum Secondary Control Reserve (SCR) in the Four German Control Areas.

\begin{tabular}{|c|c|c|c|c|c|}
\hline \multirow[t]{2}{*}{ TSO } & \multicolumn{2}{|c|}{ Maximum Load $2006^{3}$} & \multirow{2}{*}{$\begin{array}{l}\text { Recomm. Minimum SCR [MW] } \\
\text { Incremental/Decremental }\end{array}$} & \multicolumn{2}{|c|}{ Effectively Provided SCR [MW] } \\
\hline & Date & MW & & Incremental & Decremental \\
\hline EnBW & $10-J a n-06$ & 19971 & \pm 322 & +720 & -390 \\
\hline E.ON & 6-Nov-06 & 22985 & \pm 353 & +800 & -400 \\
\hline RWE & 30-Jan-06 & 32382 & \pm 439 & +1230 & -920 \\
\hline VET & 21-Feb-06 & 14970 & \pm 265 & +580 & -580 \\
\hline $\bar{\Sigma}$ & 6-Nov-06 & 74793 & \pm 728 & +3330 & -2290 \\
\hline
\end{tabular}

\subsection{Tertiary Control}

Generally, tertiary control must guarantee the provision of an adequate SCR at the appropriate time, and must optimally distribute the secondary control power to the different generators, given economic considerations. Tertiary control is tendered both as incremental (inc) and as decremental (dec) power. The former is usually provided by peak load generation units like oil or gas turbines as well as reservoir and pumped-storage power stations (in turbine operation mode). Another possibility is the provision through sheddable load (e.g., with cold storage houses). Dec power is provided by pumpedstorage power plants in pump operation mode.

Following the UCTE (2004a), there are four ways to alter the secondary control power commitment:

- Connection or tripping of power (eg., connecting gas turbines or reservoir and pumped storage power stations or increasing/decreasing the output of generators in service)

- Redistribution of output from generators participating in secondary control

- Changes of the power interchange program between interconnected companies

- Load control (e.g., centralized tele-control or controlled load-shedding).

The recommended minimum amount of tertiary control can be calculated by subtracting the recommended minimum secondary control from the largest generation capacity within the control area. Thus, the system is protected against the tripping of the largest generation unit or its network disconnection. However, the UCTE's recommended values do not account for Germany's wind generation. Between 2000-2006, the country's installed wind capacity expanded from approximately 6.000 MW to over 20.000 MW (Deutsches Windenergie-Institut, 2007). The German TSOs argue that the amount of power reserves needed for balancing wind shortfalls must increase as well. In fact, the amount of minute reserve power, which is often used for balancing the wind shortfalls, is distinctly higher in the control areas of E.ON, RWE and VET (where installed wind capacity is greatest) than in the EnBW control area.

However, this difference could also be caused by the fact that EnBW utilizes secondary control power more than tertiary control. Unfortunately, detailed quarter-hour values about the commitment of secondary control in the four control areas are not publicly available. The TSOs have published data on called-up minute reserve power only since the third quarter of 2005 (EnBW, E.ON and VET) and 
January 2006 (RWE) respectively, making it difficult to determine the extent to which the development of wind capacity effectively increased the general need for balancing power (especially the need for minute reserve power). We note that the amount of tendered minute reserve power has not increased in recent years in the control areas (except for the EnBW control area), even though the installed wind capacity has increased significantly. Rather, the amount of called-up minute reserve decreased slightly in the last quarter of 2006. However, this could be due to the new intraday-market at the EEX. ${ }^{7}$

\subsection{Market development}

The three types of power reserves were provided by separate markets in each of the four control areas until December 1, 2006, when the TSOs jointly initiated an Internet-based marketplace where potential bidders can bid separately for each type of reserve. ${ }^{8}$

The amount of reserve power that is effectively needed for balancing/regulation by each TSO cannot be precisely defined in advance, so each bidder must bid a specific amount of capacity for which it holds its generation unit(s) ready for supply. Therefore, the bidder is paid the demand rate, which has the character of an option fee. If the generation units are effectively called up to deliver energy, the bidder is paid the energy rate in addition to the demand rate. The prices for holding capacity ready for supply are passed through to the system service costs of the grid. The emerging costs of the TSOs are charged to the balancing group managers. Since the consideration of energy costs with primary control power would require separate billing (and higher transaction costs) it applies only to the procurement of secondary and tertiary control power.

The German reserve markets operate as follows. All bidders must pass a pre-qualification procedure (PQ) based upon the rules of the UCTE (2004b) as well as upon common rules of the German grid (VDN, 2003c). Once qualified, the bidder and the TSO conclude a framework agreement and the TSO calls for bids. The TSO arranges the bids submitted from the lowest to the highest capacity ( $€$ per MW) to yield a merit order. The favorable bidders are chosen according to the merit order, and the power reserves are applied when needed. For this second step, the submitted energy bids ( $€$ per MWh) are arranged from the lowest to the highest price, and the favorable bidders are chosen according to this new merit order. ${ }^{9}$ The last step of the procurement process settles the costs of provision with the respective market participants and balancing group managers.

\subsubsection{The Markets for Primary Control Power}

Primary control is tendered both as incremental and decremental power. The auctions are held biannually and the bidding periods of the four TSOs are synchronized. The amount of primary control power to be tendered conforms to the annual production volumes within the different control areas and

\footnotetext{
${ }_{8}^{7}$ For further consideration of the topic, 'wind power capacity effects and balancing needs', see Ensslin (2006).

${ }^{8} \mathrm{http}: / /$ www.regelleistung.net

9 A literature survey reveals several approaches for mixed pricing schemes (cf. Chao and Wilson, 2001; Swider and Ellersdorfer, 2006), but a consistent solution is still not at hand.
} 
is fixed by the UCTE. Together, the German TSOs procure $661 \mathrm{MW}$ of both incremental and decremental primary control power.

The auctions concern the primary control capacity (in MW) that must be provided for each day of the bidding period regardless of how much primary control is effectively called up. There are no energy rates because the precise collection of usage data would entail high transaction costs. Thus, the demand rates for primary control power must cover the expenses for the provision of primary control capacity and primary control energy. The latter is relatively small, since primary control energy is usually generated by a small increase in turbine power so that the additional costs are based only on the slightly higher fuel costs. The expenses for providing primary control capacity, on the other hand, are relatively high because capacity is normally provided by inexpensive base load or middle load plants (nuclear, lignite or hard coal), which then cannot contribute their full capacity to the wholesale market.

The prices for primary control power generally decreased from the first half of 2004 until December 2006. The control area of E.ON was the exception, where the prices remained nearly stable. Possible reasons for the price decline in the other control areas, especially for the slowly decreasing prices in the two control areas of EnBW and RWE, could be attributed to emerging competition. Considering the current prices for primary control power, we observe that the lowest price is in the control area of VET (approximately $€ 330$ per MW per day); prices in the control areas of EnBW and RWE are almost $12 \%$ higher (nearly $€ 370$ per MW per day); and the price in the E.ON control area lies in between (approximately $€ 350$ per MW per day).

On August 30, 2006, the Federal Network Agency (FNA) published desired key points for future primary control auctions (FNA, 2006d). The FNA suggested that the bidding periods for primary control power be reduced from 6 months to 1 month; the minimum bid size be set at $10 \mathrm{MW}$ with a bid increment of $1 \mathrm{MW}$; and the entire amount of primary control power be tendered in a common auction. In an effort to improve market transparency, the FNA also suggested extending the obligations to publish.

\subsubsection{The Markets for Secondary Control Power}

Secondary control power is tendered biannually with the same bidding periods and as both incremental and decremental power. In addition, an energy rate is paid to the bidder if the generation unit is effectively called up. The UCTE recommends that the amount of secondary control power to be tendered is approximately $\pm 1.400 \mathrm{MW}$. Nevertheless, the German TSOs procure $+3.300 \mathrm{MW}$ and $-2.290 \mathrm{MW}$ of reserve capacity (see 3.2). If the four operated as one area, a minimum of $\pm 810 \mathrm{MW}$ of secondary control power would have to be procured, but in today's separate markets, approximately +2.520 / - .480 MW of overcapacity are procured.

The prices for incremental secondary control power in the control areas of EnBW, RWE and VET generally remained stable from the second half year of 2003 until recently. The average prices lie between $€ 250$ (VET) and almost $€ 280$ per MW per day (RWE). The price in the E.ON control area 
increased by approximately $10 \%$ (from about $€ 190$ to $€ 210$ per MW per day). However, they are still well below those in the three other control areas. Again, the question arises about why today's prices for incremental secondary control power (e.g. in the RWE control area) are almost $€ 70$ per MW per day, (32\% higher) than in the E.ON control area.

We note that the prices for decremental secondary control power tended to increase by at least $20 \%$ (VET) to more than $60 \%$ (E.ON), whereas current prices in the E.ON control area still remained at the lower end of the scale (the price spreads were even greater than for incremental power).

In general, the different energy rates for incremental secondary control power have risen. Today, the highest maximum energy rates (almost €ct 15 per kWh) are in the EnBW control area, which is nearly $35 \%$ higher than in the control areas of E.ON and VET (both approximately $€$ ct 11 per $\mathrm{kWh}$ ) The spread between the four control areas for minimum energy rates is even greater; the highest rates are in the VET control area.

The key points issued by FNA on August 30, 2006, also included the secondary power market: reducing the bidding periods from 6 months to 1 month, and eventually including daily bidding; the minimum bid size set at $10 \mathrm{MW}$ with a bid increment of $1 \mathrm{MW}$; compliance with the respective demand rates for placing and call up of secondary control power; and extending the obligation to publish. FNA suggested linking energy rates, to the spot market prices at the EEX, to prevent optimization against the exchange price by traders or balancing group managers through premeditated usage of balancing energy. For incremental secondary control energy, FNA suggested a factor of 1.5 and for decremental secondary control energy a factor of 0.5 . It would also apply to the placing and call up of minute reserve power. The entire amount of secondary control power would be tendered in a common auction for the four control areas.

\subsubsection{The Four Markets for Minute Reserve Power}

Minute reserve power is tendered day-ahead as incremental and decremental capacity. Winning bids are paid the demand rate. If incremental minute reserve power is effectively called up - which only occurs in approximately $3 \%$ of all cases - the energy rate is paid in addition. If decremental minute reserve is called up and current is collected by the bidder, it must pay the energy rate to the TSO. In the latter case the energy rate is usually very low or zero.

Until November 30, 2006, there were four different, time-separated auction markets for minute reserve power. Now the auctions are day-ahead and are held each working day. Auctions for weekends, Mondays and holidays are held on the last working day prior. The auctions occur successively to increase the number of bidders and the bidding volumes. VET opens bidding at 9 AM; E.ON at 10:30 AM; the spot market at the EEX opens at noon; and minute reserve power auctions in the EnBW and the RWE control area open at 1:30 PM and 3 PM respectively. With several 'bidding rounds' bidders are supposed to place higher bids in the first rounds. This seems reasonable because there is another possibility to win the auction with a lower placed bid in one of the next rounds. One drawback of the EnBW and RWE minute reserve auctions is low liquidity. Since the spot market occurs beforehand, 
EnBW and RWE are expected to face higher prices which must be accepted to meet their requirements.

Contracts for incremental and decremental minute reserve power are awarded separately in the four control areas. However, there are differences regarding the different tariff time bands. The EnBW control area has two: Haupttarif (HT) spans Monday through Friday from 8 AM to 8 PM, and Nebentarif (NT) spans Monday through Friday from 8 PM to 8 AM and weekends and holidays from 12 AM to 12 PM. The E.ON control area has two: HT spans Monday through Friday from 6 AM to 10 PM and weekends and holidays from 8 AM to 1 PM; NT spans the other times. The RWE control area has five: 12 AM to 4 AM, 4 AM to 8 AM, 8 AM to 4 PM, 4 PM to 8 PM and 8 PM to 12 PM. The VET control area has six: RWEs largest time block from 8 AM to 4 PM is split up in two 4-hour blocks. The minimum bid size in the EnBW, RWE and VET control areas is $30 \mathrm{MW}$ and in the E.ON control area, $50 \mathrm{MW}$. The amounts of contracted minute reserve power differ according to the size of the control area (Table 3).

The average demand rates for incremental minute reserve are well below the prices for secondary control and for primary control because the latter two types of control are more technically challenging. However, the minimum energy rates for minute reserve power are greater than the minimum energy rates for secondary control power because minute reserve power is mainly provided by peak-load units, which have higher variable costs than base- or middle-load plants. The prices for decremental minute reserve are close to 0 (Table 3 ).

Table 3: Minute Reserve Power Auctions in the Four German Control Areas from April 1, 2003 to November 30, 2006

\begin{tabular}{|c|c|c|c|c|c|c|c|c|c|}
\hline TSO & Procurement on... & $\begin{array}{c}\text { Incremental } \\
\text { Capacity [MW] }\end{array}$ & $\begin{array}{c}\text { Av. Demand } \\
\text { Rate }[€ / M W \\
\text { per day] }\end{array}$ & $\begin{array}{c}\text { Av. Minimum } \\
\text { Energy Rate } \\
\text { [€ct per } \mid W h]\end{array}$ & $\begin{array}{c}\text { Av. Maximum } \\
\text { Energy Rate } \\
{[€ c t \text { per } \$ W h]}\end{array}$ & $\begin{array}{c}\text { Decremental } \\
\text { Capacity [MW] }\end{array}$ & $\begin{array}{c}\text { Av. Demand } \\
\text { Rate }[€ / \mathrm{MW} \\
\text { per day] }\end{array}$ & $\begin{array}{c}\text { Av. Minimum } \\
\text { Energy Rate } \\
\text { [€ct per } \mathrm{WWh}]\end{array}$ & $\begin{array}{c}\text { Av. Maximum } \\
\text { Energy Rate } \\
\text { [€ct per } \mathrm{HWh}]\end{array}$ \\
\hline \multirow[t]{3}{*}{ EnBW } & working days & +478 & 228.39 & 14.59 & 147.79 & -345 & 55.46 & 0.00 & 0.15 \\
\hline & weekends/holidays & +479 & 51.19 & 13.91 & 129.47 & -345 & 104.34 & 0.00 & 0.01 \\
\hline & all days & +478 & 171.67 & 14.38 & 141.79 & -345 & 71.30 & 0.00 & 0.11 \\
\hline \multirow[t]{3}{*}{ E.ON } & working days & +1100 & 215.96 & 12.08 & 158.51 & -400 & 47.40 & 0.00 & 0.17 \\
\hline & weekends/holidays & +1100 & 52.21 & 11.89 & 141.05 & -400 & 87.73 & 0.00 & 0.05 \\
\hline & all days & +1100 & 163.65 & 12.02 & 152.52 & -400 & 60.44 & 0.00 & 0.13 \\
\hline \multirow[t]{3}{*}{ RWE } & working days & +1009 & 236.43 & 12.18 & 179.44 & -763 & 59.81 & 0.00 & 0.89 \\
\hline & weekends/holidays & +1019 & 53.74 & 10.87 & 144.57 & -760 & 119.31 & 0.00 & 0.20 \\
\hline & all days & +1012 & 177.27 & 11.78 & 168.46 & -762 & 78.91 & 0.00 & 0.67 \\
\hline \multirow{3}{*}{ VET } & working days & +737 & 227.04 & 12.37 & 179.20 & -564 & 60.74 & 0.00 & 0.15 \\
\hline & weekends/holidays & +737 & 52.06 & 11.16 & 142.34 & -563 & 117.37 & 0.00 & 0.05 \\
\hline & all days & +737 & 171.12 & 11.98 & 167.36 & -564 & 79.02 & 0.00 & 0.12 \\
\hline
\end{tabular}

In 2006, minute reserve power was called up in only a few hours with RWE having the highest and EnBW the lowest rate. The maximum capacity values needed closely correlated with the procured capacities (Table 4).

The development of minute reserve power pricing occurred in two phases (Figure 3). In the first 22 months of the considered period (April 1, 2003 to the end of January 2005), the average demand rate tended to decrease significantly. The maximum value in this period was approximately $€ 480$ per MW per day; the average was approximately $€ 190$ per MW per day (tending downwards) and, for the first time, prices dropped below $€ 100$ per MW per day for a longer period. However, after a positive 'shock', prices reverted slowly to their mean level. The EEX day-ahead peak load hour prices 
remained relatively constant; the gently declining curve fluctuated around a mean of approximately $€$ 40. The next 22 months (from February 2005 to November 2006) were characterized by significantly higher price spikes. There were 21 days when the prices for incremental minute reserve power were higher than $€ 1.000$ per MW per day. There were 214 days when the prices were lower than $€ 100$ per MW per day, compared to only 26 days in the previous 22 months. The average price was approximately $€ 263$ per MW per day, significantly greater ( $+37 \%$ ) than in the previous 22 months. From January to November 2006, the average price remained at $€ 208$ per MW per day despite a huge peak at the end of July. After this 'shock', the prices reverted more quickly to their mean level than in the previous 22 months. Overall however, they rose faster than they declined.

Table 4: Effectively Called-up Minute Reserve Power in the Four German Control Areas from January 1, 2006 to December 31, 2006

\begin{tabular}{|c|c|c|c|c|c|c|c|c|c|}
\hline \multirow[t]{2}{*}{ TSO } & \multirow[t]{2}{*}{ Commitment on... } & \multicolumn{4}{|c|}{ Incremental Minute Reserve Power } & \multicolumn{4}{|c|}{ Decremental Minute Reserve Power } \\
\hline & & $\begin{array}{l}\text { Called-up abs. } \\
\text { [quarter hours] }\end{array}$ & $\begin{array}{c}\text { Called-up rel. } \\
{[\%]}\end{array}$ & $\begin{array}{l}\text { Max. Capacity } \\
\text { Needed [MW] }\end{array}$ & $\begin{array}{l}\text { Av. Capacity } \\
\text { Needed [MW] }\end{array}$ & $\begin{array}{l}\text { Called-up abs. } \\
\text { [quarter hours] }\end{array}$ & $\begin{array}{c}\text { Called-up rel. } \\
{[\%]}\end{array}$ & $\begin{array}{l}\text { Max. Capacity } \\
\text { Needed [MW] }\end{array}$ & $\begin{array}{l}\text { Av. Capacity } \\
\text { Needed [MW] }\end{array}$ \\
\hline \multirow{3}{*}{ EnBW } & working days & 67 & 0.19 & +390 & +215 & & & & \\
\hline & weekends/holidays & 2 & 0.01 & +440 & +265 & 0 & - & - & - \\
\hline & all days & 69 & 0.20 & +440 & +216 & & & & \\
\hline \multirow[t]{3}{*}{ E.ON } & working days & 258 & 0.74 & +900 & +272 & 15 & 0.04 & & -160 \\
\hline & weekends/holidays & 38 & 0.11 & +850 & +271 & 9 & 0.03 & -300 & -206 \\
\hline & all days & 296 & 0.84 & +900 & +272 & 24 & 0.07 & & -177 \\
\hline \multirow{3}{*}{ RWE } & working days & 1266 & 3.61 & +1080 & +233 & 879 & 2.51 & -945 & -271 \\
\hline & weekends/holidays & 410 & 1.17 & +955 & +232 & 399 & 1.14 & -760 & -351 \\
\hline & all days & 1676 & 4.78 & +1080 & +233 & 1278 & 3.65 & -945 & -296 \\
\hline \multirow[t]{3}{*}{ VET } & working days & 107 & 0.31 & +500 & +176 & 185 & 0.53 & & -208 \\
\hline & weekends/holidays & 36 & 0.10 & +340 & +186 & 175 & 0.50 & -530 & -234 \\
\hline & all days & 143 & 0.41 & +500 & +179 & 360 & 1.03 & & -220 \\
\hline
\end{tabular}

Figure 3: Weighted Average Demand Rates for Incremental Minute Reserve Power in the Four German Control Areas and EEX Day-Ahead Peak Load Hour Prices from April 1, 2003 to November 30, 2006

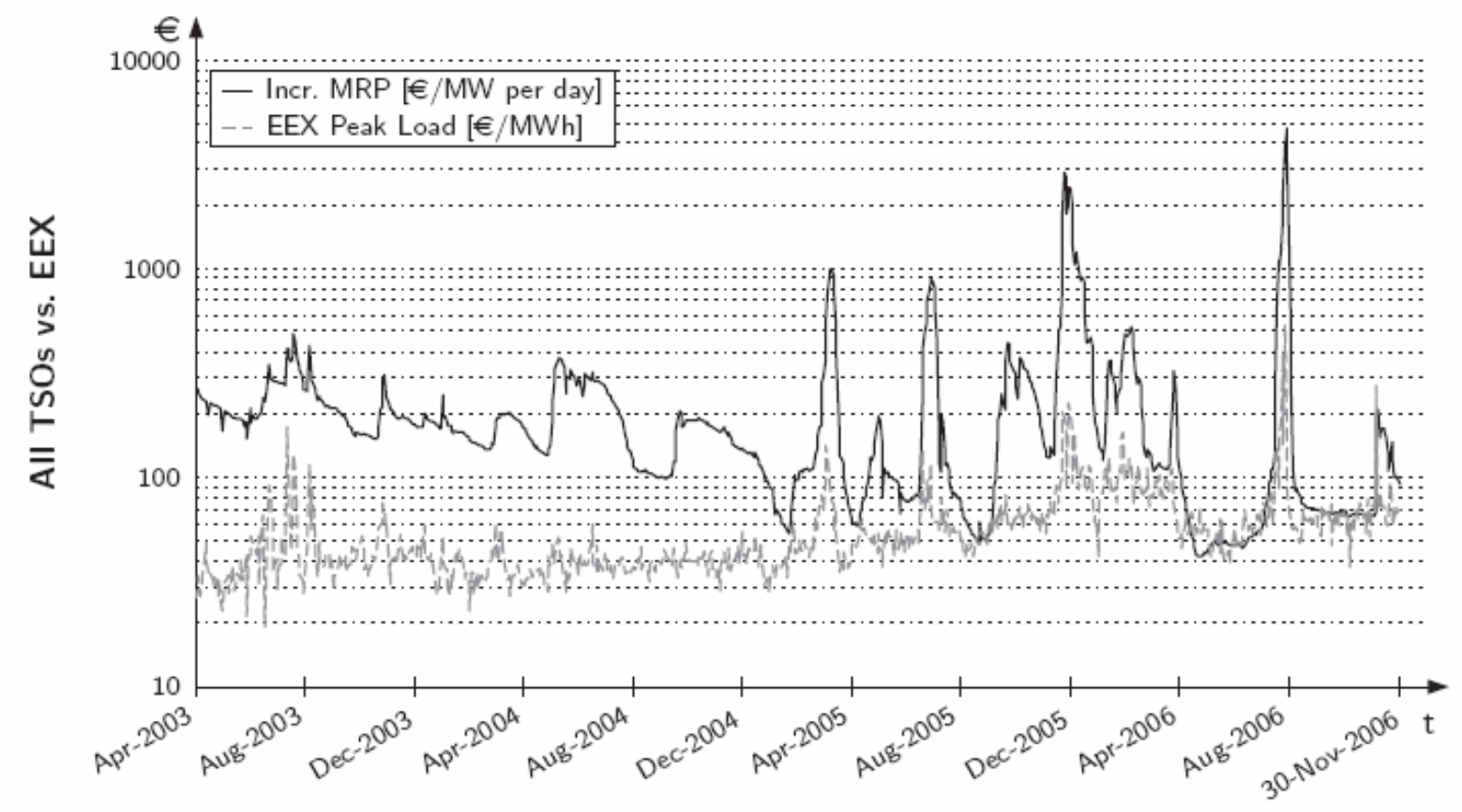

Increased volatility and higher average price scenarios should favor the use of long-term contracts to procure minute reserve power. In fact, the German TSOs voted for procuring $50 \%$ of minute reserve 
power through an annual bidding and another 30\% through a monthly bidding. According to the TSOs, only $20 \%$ of all minute reserve power should be tendered day-ahead (cf. FNA, 2006a). The TSOs asserted that short-term procurement could also jeopardize system stability and security of supply. However, the FNA rejected their assertions, arguing (FNA, 2006b) that short-term procurement is the only vehicle that both maintains and improves competitiveness in the corresponding markets.

Since December 1, 2006, the German TSOs have procured minute reserve power through competitive bidding in a single Internet-based market, which enables the TSOs to comply with sec. 22, para. 2 EnWG (EnWG, 2005) and sec. 6 StromNZV (StromNZV, 2005). The auctions are synchronized, i. e., the reserve power for the four control areas is tendered jointly at $10 \mathrm{AM}$, prior to the day-ahead spot market at the EEX. The minimum bid size of $15 \mathrm{MW}$ was set by the FNA for both incremental and decremental minute reserve power, with a bidding increment of 1 MW. As per sec. 6, para. 4 StromNZV 2005, capacity can be pooled to reach the minimum bid size. However, the contributing generation units must be situated within the control area.The four control areas now have six tariffs: 0 AM to 4 AM, 4 AM to 8 AM, 8 AM to $12 \mathrm{PM}, 12$ PM to 4 PM, 4 PM to 8 PM and 8 PM to $12 \mathrm{PM}$.

Bidding is still based on the demand rates (the pricing scheme remained pay-as-bid). For each day, the TSOs publish a common merit order for both incremental and decremental minute reserve power, and for each of the six tariff time blocks. The daily prices are the weighted average sum of all accepted bids for the six blocks. On December 1, 2006, the average price for procuring incremental minute reserve power was $€ 17$ per MW per day, which was more than $80 \%$ lower than prices in previous days. ${ }^{10}$ A price 'shock' that was not connected to the price development at the EEX followed soon after. At the end of December 2006, the prices began to revert to the EEX peak load level. In the period considered, the German TSOs procured 3.320 MW of incremental and -2.001 MW of decremental minute reserve power; thus the overall amount did not noticeably decrease. We note that between December 1, 2006 and February 23, 2007, the average price level is well below the values of the previously separated markets.

\section{Correlation and Cost Analyses}

Irrespective of the price level, price development in minute reserve markets should correlate with the short-term prices at the EEX because both products are quasi-substitutes. Further, the price of minute reserve power is determined by the revenues that could be generated through selling power in the spot market. On the other hand, since incremental minute reserve power is called up in only $1.5 \%$ of all cases, it is normally provided through gas or oil turbines that are unlikely to affect the spot market. However, rising spot prices should cause rising prices for minute reserve power and vice versa; otherwise balancing group managers could exploit these arbitrage possibilities by deviating from their announced schedules.

\footnotetext{
${ }^{10}$ This is an example of what Crampton and Stoft call the 'guess the clearing price' auction.
} 
Our correlation analysis looked at price linkage and price level adequacy of the incremental minute reserve power followed by a study of the investment and operations costs for a single cycle gas turbine. The analysis uses the price curves of the four control areas and the EEX day-ahead peak load.from April 2003 to November 2006. The different bidding times of the four markets - the VET and E.ON markets take place before the EEX spot market, EnBW and RWE thereafter - require that the today's prices of E.ON and VET are compared with the yesterday's prices of EnBW, RWE and the EEX.

Figure 4 displays a comparison of the log-returns of the weighted average incremental minute reserve power prices in the four control areas and the log-returns of the EEX day-ahead peak load hour prices. The EEX prices had a significantly higher variance (0.044) than the control areas (0.029). The average of both log-returns was approximately zero. However, there were 456 values less than zero and 458 values greater than zero in the EEX log-returns compared to 575 values less than zero and 339 values greater than zero in the control area log-returns. This indicates that EEX prices waxed and waned in the same dimension, but that control-area prices increased more than they declined (i.e., there was a slower reversion to their average mean level).

Table 5 shows the results of the correlation analysis for the first 22 months of the period (April 2003 to November 2006). The highest correlations between the log-returns of the four incremental minute reserve power prices occurred between the control areas of EnBW and RWE and between E.ON and VET. This appears logical, since EnBW and RWE procured minute reserve power for the next day after the EEX spot market, and E.ON and VET procured in advance. Table 6 shows the correlations for the second 22 months. The strongest correlation occurred between RWE and the EEX $(+0.527)$. The three other control areas showed a correlation with the EEX log-returns of approximately +0.4 . Thus, all values were significantly higher than in the first 22 months. Reducing the sample to the period from January to November 2006 improved the correlation values even further. 
Figure 4: Log-Returns of Weighted Average Incremental Minute Reserve Power Prices in the Four German Control Areas and of the EEX Peak Load Hour Prices from April 2003 to November 2006 (adjusted data, logarithmic scale)

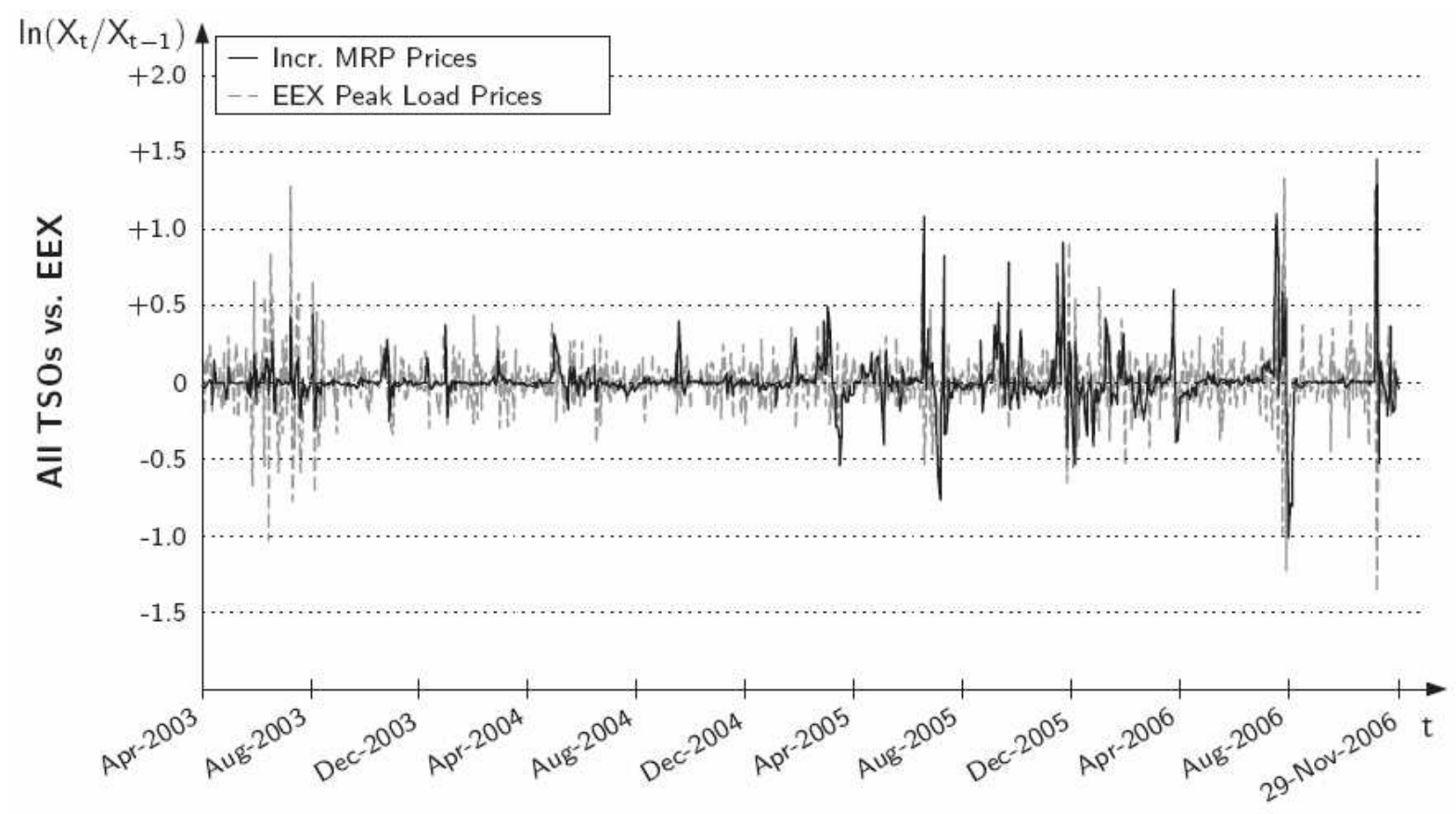

Table 5: Correlation Matrix for the Incremental Minute Reserve Power Prices in the Four German Control Areas and the EEX Day-Ahead Peak Load Hour Prices from April 2003 to January 2005

\begin{tabular}{lccccc}
\hline$n=456$ & EnBW & E.ON & RWE & VET & EEX \\
\hline EnBW & $1^{* * *}$ & $0.243^{* * *}$ & $0.439^{* * *}$ & $0.121^{* * *}$ & $0.325^{* * *}$ \\
E.ON & - & $1^{* * *}$ & $-217^{* * *}$ & $0.381^{* * *}$ & $0.078^{*}$ \\
RWE & - & - & $1^{* * *}$ & 0.051 & $0.489^{* * *}$ \\
VET & - & - & - & $1^{* * *}$ & $-0.079^{*}$ \\
EEX & - & - & - & $1^{* * *}$ \\
\hline
\end{tabular}

Table 6: Correlation Matrix for the Incremental Minute Reserve Power Prices in the Four German Control Areas and the EEX Day-Ahead Peak Load Hour Prices from February 2005 to November 2006

\begin{tabular}{lccccc}
\hline$n=459$ & EnBW & E.ON & RWE & VET & EEX \\
\hline EnBW & $1^{* * *}$ & $0.735^{* * *}$ & $0.792^{* * *}$ & $0.790^{* * *}$ & $0.412^{* * *}$ \\
E.ON & - & $1^{* * *}$ & $0.771^{* * *}$ & $0.938^{* * *}$ & $0.433^{* * *}$ \\
RWE & - & - & $1^{* * *}$ & $0.812^{* * *}$ & $0.527^{* * *}$ \\
VET & - & - & - & $1^{* * *}$ & $0.432^{* * *}$ \\
EEX & - & - & - & - & $1^{* * *}$ \\
\hline
\end{tabular}

For a strong correlation between the log-returns of the common market prices and the EEX day-ahead peak load prices, it would be advisable to procure the day-ahead minute reserves timely after the EEX spot market, but we note that this would reduce liquidity on the power reserve market and increase the danger of missing capacity. Moreover, low liquidity could cause the prices to be significantly higher. To address such concerns, the FNA decided to hold the power reserve market before the EEX spot market. A correlation analysis with the log-returns of the common incremental minute reserve power prices and the log-returns of the EEX day-ahead peak load hour prices from December 4, 2006 to 
February 23, 2007 shows the absence of a correlation between these values $(r=+0.119$, but not significant). This resulted from a spike in the prices for incremental minute reserve at the beginning of December 2006 which was not caused by rising EEX prices or by other external influences. Since the end of December 2006, prices declined almost steadily to today's current level (give level). However, it is likely that the previous values between +0.4 and +0.5 or even higher values will be achieved again.

Beside the correlation analysis it is tested whether the (average) demand and energy rates on the German market for incremental minute reserve power are on a fair level. Therefore, the costs of providing incremental minute reserve power shall be estimated. Normally, incremental minute reserve power is provided by peak load generation units such as pumped-storage power plants or gas or oil turbines. For this segment of our analysis, we assumed that a non-spinning single cycle gas turbine provides the minute reserve power. According to the manufacturer, the turbine has a rate of change of $8 \%$ per minute. Thus, it takes 12.5 minutes to ramp up to full power, which should be sufficient for the technical provision of minute reserve power. To estimate the fair demand and energy rates for incremental minute reserve power, it is necessary to calculate: (1) the capital cost and other fixed cost as annuity, (2) the fuel cost in $€ / G J$ divided by the plant efficiency in $\mathrm{kWh} / \mathrm{GJ}$ and (3) the external cost in $€ / \mathrm{kWh}$. The turbine's capacity of $30 \mathrm{MW}$ is completely bid on the power reserve market. The capital cost per year can be calculated as investment cost divided by the amortization period, which normally corresponds to the expected economic lifetime. Considering the interest rate $i$, it is assumed that the investment is realized with both equity and debt. The Capital Asset Pricing Model is adopted to estimate the Weighted Average Cost of Capital.

Under the assumption that the considered bidder, e. g. a German municipality, has some knowledge about electricity markets in general but is not yet operating in the power reserve market, the following values for the above variables appear appropriate:

- The level of gearing $g$ is assumed to be 0.6 , i.e., $60 \%$ of the investment are covered with debt and $40 \%$ with equity

- The debt premium is taken as $2 \%$

- The marginal corporate tax rate $\mathrm{t}$ is $25 \%$

- The risk-free rate of return is taken as $4 \%$

- The market rate of return is taken as $10 \%$

- $\quad \beta$ is assumed to be unity.

We can now calculate a WACC of $6.7 \%$ with the cost of debt being $6 \%$ and the cost of equity being $10 \%$. The expected economic lifetime of the turbine is assumed to be 15 years, which results in an annuity of $10.77 \%$ of the investment cost. 
If the investment cost of a single-cycle gas turbine is assumed to be approximately $€ 235$ per $\mathrm{kWel}$ including installation costs and interest during construction, ${ }^{11}$ the resulting annuity is approximately $€$ 760.000 per year. Since the gas turbine is virtually "on" at all times, its capacity is bid for 8.700 hours per year. This results in an investment cost of almost $€ 70$ per MW per day which represents the theoretically maximum demand rates for incremental minute reserve power. However, we should include the costs of O\&M, labor, bidding procedures, and, IT connection and support. Nevertheless, the large spread between actual prices (on average $€ 136$ per MW per day in 2006) and theoretical prices suggests that the markets have not attained full competition.

The maximum energy rates, on the other hand, correspond mainly to the fuel cost plus variable O\&M cost, start-up cost and the costs for emission allowances. The fuel cost can be calculated assuming an efficiency of $35 \%$ resulting in approximately $€$ ct 6.2 per $\mathrm{kWh}$. Assuming O\&M cost of $€$ ct 0.5 per $\mathrm{kWh}$ and a large start-up cost, we expect to see energy rates between $€$ ct 7.0 and $€$ ct 8.0 per $\mathrm{kWh}$, which corresponds to today's lowest average bid-prices.

The preliminary results of our analysis showed that well-designed incentives can encourage a generator to bid into the power reserve market instead of the EEX spot market. Under the assumption that the generator can sell the entire capacity of $30 \mathrm{MW}$ for four peak hours per day at the EEX, and every day is paid the prices for the four most expensive hours, its income in 2006 would total $€ 3.5$ million ( $€ 9.465$ per day). However, the generator must generate $120 \mathrm{MWh}$ every day; assuming the variable cost is $€$ ct 7.0 per $\mathrm{kWh}$ leaves about $€ 1.000$ revenue per day. If the generator bids the entire capacity of $30 \mathrm{MW}$ on the minute reserve power market and is paid the average demand rate, its income in 2006 would total nearly $€ 1.5$ million ( $€ 4.080$ per day). When the $30 \mathrm{MW}$ turbine is called up, the generator is also paid the energy rate, and thus yearly income is even higher. In summary, our analysis showed prices for minute reserve power declined compared to the day-ahead peak load hour prices on the EEX spot market. This brief analysis corroborates our theory that in Germany at least, demand rates remain excessive and their prices are uncompetitive.

\section{Conclusion}

Both the theoretical discussion and the empirical analysis of the German power reserve markets show that the markets have undergone a remarkable development in the last seven years. While the current competitively organized markets offer relatively lower prices, there is still room for improvement. The most important requirement for economically efficient power reserve markets is the joint operation of the four German control areas. This would reduce the over-procurement of power reserves because

\footnotetext{
${ }^{11}$ Basically, gas turbine prices are not officially published by manufacturers, and are subject to negotiation. Different sources quote turnkey costs for single cycle gas turbines ranging between US\$ 300 and US\$ 650 (cf. e. g. Boyce, 2001, p. 8). Following Gas Turbine World (2005), the prices for gas turbines have recently returned to 1998 levels. The Independent Market Operator Administering the Western Australia Wholesale Electricity Market (2005) stated that the capital cost of an open cycle gas turbine would be about US\$ 160 per $\mathrm{kWel}$, based on the price for a Siemens 163 MW V94.2 machine. According to the relative small size of the gas turbine considered here $(30 \mathrm{MW})$, a price of US\$300 (_e 235$)$ per $\mathrm{kWel}$ appears reasonable.
} 
there would be no need to hedge against the simultaneous trip of four power plants. Furthermore, simultaneously occurring balance deviations in two control areas would be balanced self-actingly. We showed that the joint operation of the four control areas could reduce the minimum amount of secondary control power from approximately $\pm 1.550 \mathrm{MW}$ to $\pm 800 \mathrm{MW}$. However, it would require the German TSOs to comply with the UCTE's requirements for reserve power procurement. Since the price spreads between the four control areas are still excessive, it would appear advisable to procure primary and secondary control power through common markets. Indeed, the fact that the UCTE requires that two-thirds of secondary control power be procured within the respective control area suggests that price differences will remain. Nevertheless, joint bidding should have a price-reducing effect. The effect will be even greater for primary control.

Irrespective of united or separate control area operations, we suggest that the TSOs should implement the UCTE's recommendations. Although the UCTE defines both the amount of primary control power to be procured and the minimum amount of secondary and tertiary control, the TSOs may still specify the amount of secondary and tertiary control. Even if the four control areas do not operate as one, the amount of secondary control could be reduced by +1.800 / $-750 \mathrm{MW}$. On the contrary, the amount of incremental minute reserve power would have to be increased by $+570 \mathrm{MW}$.

It is obvious that short-term bidding results in more volatile pricing because the time period between the conclusion of a contract and its exercise date is abbreviated and more information about the market at the time of delivery is available. We suggest, however, that primary and secondary control power should be tendered quarterly or monthly. Shorter bidding periods would increase market liquidity and more market players could participate in the auctions because of enhanced information about available generation capacity. While shorter bidding periods are no guarantee for declining prices, they are necessary if the policy goal is to increase competition. We suggest that future research should analyze the extent to which it is reasonable to procure minute reserve power through intraday (hour-ahead) markets.

\section{References}

[BET Aachen 2003] BET Aachen: Regelmarkt - Gutachten zu Marktgestaltung, Beschaffungskosten und Abrechnung von Regelleistung und Regelenergie durch die deutschen Übertragungsnetzbetreiber. Version: October 2003. http://www.betaachen.de/download/BET\%20REM\%20Gutachten\%20Endfassung\%20031031.pdf, Last checked: 20 September 2006

[BET Aachen 2006] BET Aachen: Studie zur Marktgestaltung der Regel- und Ausgleichsenergie vor dem Hintergrund des neuen EnWG. Version: January 2006. http://www.bet-aachen. de/download/060116RAE-StudieEndgültig.pdf, Last checked: 15 February 2007

[Bower and Bunn 2000] Bower, John ; Bunn, Derek: A Model-Based Comparison of Pool and Bilateral Market Mechanisms for Electricity Trading. In: The Energy Journal 21 (2000), July, No. 3, S. 1-29 
[Boyce 2001] Boyce, Meherwan P.: Gas Turbine Engineering Handbook: Incompressible Flow Turbomachines. 2nd Edition. Houston/Texas : Gulf Professional Publishing, 2001

[Bundesrepublik Deutschland Finanzagentur GmbH 2007] Bundesrepublik Deutschland Finanzagentur GmbH: Website of the Bundesrepublik Deutschland Finanzagentur GmbH. Version: February 2007. http://www.deutsche-finanzagentur.de, Last checked: 15 February 2007

[Chao and Wilson 2001] Chao, Hung-po ; Wilson, Robert: Multi-Dimensional Procurement Auctions for Power Reserves: Robust Incentive-Compatible Scoring and Settlement Rules. Version: March 2001. http://faculty-gsb.stanford.edu/wilson/archive/pdf/ChaoWilson6.pdf, Last checked: 15 February 2007

[Cramton and Stoft 2006] Cramton, Peter ; Stoft, Steven: Uniform-Price Auctions in Electricity Markets. Version: March 2006. http://stoft.com/metaPage/lib/cramton-stoft-2006-03-clearingprice-markets.pdf, Last checked: 15 February 2007

[Deutsches Windenergie-Institut 2007] Deutsches Windenergie-Institut: Pressemitteilung VDMA/BWE/DEWI vom 16.01.2007: Aufstellungszahlen der Windenergienutzung in Deutschland, Stand 31.12.2006. Version: January 2007. http://www.dewi.de/dewi_neu/englisch/themen/statistic/statistik311206.pdf, Last checked: 15 February 2007

[EEX AG 2007] EEX AG: Website of the European Energy Exchange. Version: February 2007. http://www.eex.de/, Last checked: 15 February 2007

[EnBW AG 2006] EnBW AG: Geschäftsbericht 2005. Version: 2006. http://www.enbw.com/content/de/investoren/_media/_pdf/gb_2005.pdf, Last checked: 15 February 2007

[EnBW Transportnetze AG 2007] EnBW Transportnetze AG: Website Regelenergie der EnBW Transportnetze AG. Version: February 2007. http://www.enbw.com/content/de/ netznutzer/strom/regelenergie/, Last checked: 15 February 2007

[EnBW Transportnetze AG et al. 2007] EnBW Transportnetze AG ; E.ON Netz GmbH ; RWE Transportnetz Strom GmbH ; Vattenfall Europe Transmission GmbH: Website Internetplattform zur Ausschreibung von Regelleistung. Version: February 2007. http://www.regelleistung.net, Last checked: 15 February 2007

[Ensslin 2006] Ensslin, Cornel: The Influence of Modelling Accuracy on the Determination of Wind Power Capacity Effects and Balancing Needs, Kassel University, Diss., 2006 [EnWG 1998] EnWG: Gesetz zur Neuregelung des Energiewirtschaftsrechts/Veröffentlicht am 24. April 1998. In: Bundesgesetzblatt, Teil 1, Nr. 23, S. 730-736. Version: April 1998. http://217.160.60.235/BGBL/bgbl1f/b198023f.pdf, Last checked: 15 February 2007

[EnWG 2005] EnWG: Zweites Gesetz zur Neuregelung des Energiewirtschaftsrechts/Veröffentlicht am 7. Juli 2005. In: Bundesgesetzblatt, Teil 1, Nr. 42, S. 1970-2018. Version: July 2005. http://217.160.60.235/BGBL/bgbl1f/bgbl105s1970.pdf, Last checked: 15 February 2007 
[E.ON AG 2006] E.ON AG: Geschäftsbericht 2005. Version: 2006. http://www.eon.com/de/ downloads/GB_D_komplett_geschuetzt_060309.pdf, Last checked: 15 February 2007

[E.ON Netz GmbH 2007] E.ON Netz GmbH: Website Ausschreibung von Regelleistung bei E.ON Netz. Version: $\quad$ February $2007 . \quad$ http://www.eonnetz.com/frameset_german/net/net_adv_rul_energy/net_advertisement_rule_energy.jsp, Last checked: 15 February 2007

[ETSO 2006] ETSO: Key Issues in Facilitating Cross-Border Trading of Tertiary Reserves and Energy Balancing. Version:May 2006. http://www.etso-net.org/upload/documents/Report\%20BM\%201805-06.pdf, Last checked: 15 January 2007

[ETSO 2007a] ETSO: Balance Management Harmonisation and Integration - 4th Report. Version: January 2007. http://www.etso-net.org/upload/documents/4th\%20Report\%20BM.pdf, Last checked: 15 February 2007

[ETSO 2007b] ETSO: Website of the Association of the European Transmission System Operators. Version: February 2007. http://www.etso-net.org/, Last checked: 15 February 2007 [European Commission 2004] European Commission: SETREC-GO: RE-GO Phase 3 report: GO as a tool for tracking electricity attributes. Version:August 2004. http://www.re-go.info/downloads/tracking.pdf, Last checked: 15 February 2007

[European Commission 2007] European Commission: Inquiry pursuant to Article 17 of Regulation (EC) No 1/2003 into the European gas and electricity sectors (FinalReport). Version: January 2007. http://ec.europa.eu/comm/competition/antitrust/others/sector_inquiries/energy/final_report.pdf, Last checked: 15 February 2007

[European Parliament/European Council 1996] European Parliament/European Council: Directive 96/92/EC of the European Parliament and of the Council of 19 December 1996concerning common rules for the internal market in electricity. In: Official Journal of the European Union, L 027/20-L 027/29. Version:December $1996 . \quad \mathrm{http} / /$ eurlex.europa.eu/LexUriServ/LexUriServ.do?uri=CELEX:31996L0092:EN:HTML, Last checked: 15 February 2007

[European Parliament/European Council 2003] European Parliament/European Council: Directive 2003/54/EC of the European Parliament and of the Council/Published on 26 June 2003. In: Official Journal of the European Union, L 176/37-L 176/55. Version: June 2003. http://europa.eu.int/eurlex/pri/en/oj/dat/2003/1_176/1_17620030715en00370055.pdf, Last checked: 15 February 2007

[FCO 2000a] FCO: Beschluss im Zusammenschlussverfahren - Az. B8-40000-U-309/99 $\begin{array}{lllll}\text { RWE/VEW } & \text { / Bundeskartellamt }\end{array}$ http://www.bundeskartellamt.de/wDeutsch/download/pdf/Fusion/Fusion99/B8_309_99.pdf, Last checked: 15 February 2007

[FCO 2000b] FCO: Beschluss im Zusammenschlussverfahren - Az. B8-40200-U-132/00 E.ON/HeinGas/HEW / Bundeskartellamt (BkartA). Version: 2000. 
http://www.bundeskartellamt.de/wDeutsch/download/pdf/Fusion/Fusion00/B8_132_00.pdf, Last checked: 15 February 2007

[FCO 2002] FCO: Fünfzehntes Hauptgutachten der Monopolkommission gemäß $§ 44$ Abs. 1 Satz 1 GWB: Wettbewerbspolitik im Schatten "Nationaler Champions". Kurzfassung. Version: 2002/2003. http://www.monopolkommission.de/haupt_15/sum_h15_de.pdf, Last checked: 15 February 2007

[FCO 2006] FCO: B8-88/05-1/2 - Sachstandspapier zur Vorbereitung der mündlichen Verhandlung in Sachen Emissionshandel und Strompreisbildung. Version: March 2006. http://www.bundeskartellamt.de/wDeutsch/download/pdf/06_Sachstandspapier_Emissionshandel_ und_Strompreisbildung_kor_.pdf, Last checked: 15 February 2007

[Federal Ministry of Economics and Technology 2006] Federal Ministry of Economics and Technology: Monatliche Erdgasbilanz und Entwicklung der Grenzübergangspreise ab 1991. Version: December 2006. http://www.bmwi.de/BMWi/Navigation/Service/publikationen,did=53736.html, Last checked: 15 February 2007

[FNA 2006a] FNA: Ausschreibung der Regelenergie nach StromNZV - Umsetzungskonzept der deutschen ÜNB. Version: April 2006. http://www.bundesnetzagentur.de/media/archive/4598.pdf, Last checked: 15 February 2007

[FNA 2006b] FNA: BK6-06-012 - Beschluss zu Verfahren zur Ausschreibung von Regelenergie in $\begin{array}{llll}\text { Gestalt der } & \text { Minutenreserve. }\end{array}$ http://www.bundesnetzagentur.de/media/archive/7318.pdf, Last checked: 15 February 2007

[FNA 2006c] FNA: Eckpunktepapier zu den Verfahren der Ausschreibungsbedingungen für Sekundärregelleistung. Version:August 2006. http://www.bundesnetzagentur.de/media/archive/8400.pdf, Last checked: 15 February 2007

[FNA 2006d] FNA: Eckpunktepapier zu den Verfahren der Ausschreibungsbedingungen Primärregelenergie. $\quad$ Version:August 2006. http://www.bundesnetzagentur.de/media/archive/8398.pdf, Last checked: 15 February 2007

[Gas Turbine World 2005] Gas Turbine World: Handbook. Pequot Publishing, 2005

[Huschens 2005] Huschens, Stefan: Theorie und Methodik der Statistik - 5. Auflage. Version:October 2005. http://www.tu-dresden.de/wwqvs/haupt/06SS/TMStat-2005-10-10.pdf, Last checked: 15 February 2007

[Independent Market Operator Administering the Western Australia Wholesale Electricity Market 2005] Independent Market Operator Administering the Western Australia Wholesale Electricity Market: Draft Report: Maximum Reserve Capacity Price for the 2008/09 Capacity Year. Version: December 2005. http://www.imowa.com.au/Attachments/MAX\%20RC\%20Price\%20Draft\%20Public\%20Report_R ev0.pdf, Last checked: 1 December 2006 
[Kahn et al. 2001] Kahn, Alfred E. ; Cramton, Peter C. ; Porter, Robert H. ; Tabors, Richard D.: Uniform Pricing or Pay-as-Bid Pricing: A Dilemma for California and Beyond. In: The Electricity Journal 14 (2001), July, No. 6, S. 70-79

[Nuovo Pignone S.p.A. ] Nuovo Pignone S.p.A.: General Electric: Gas Turbines Catalog. http://www.geoilandgas.com/businesses/ge_oilandgas/en/brochure_download/2005_O\&G_Gas_Tu rbines.pdf, Last checked: 15 February 2007

[Poll 2002] Poll, F.: Aufgaben des Hoch- und Höchstspannungnetzes. In: Vortrag vor dem Rotary Club Trier-Porta. Trier, June 2002

[Rebours and Kirschen 2005] Rebours, Yann ; Kirschen, Daniel: A Survey of Definitions and Specifications of Reserve Services. Version:October 2005. http://www.eee.manchester.ac.uk/research/electricalenergyandpowersystems/publications/reportsth eses/aoe/rebours\%20et\%20al_tech\%20rep_2005B.pdf, Last checked: 15 February 2007

[Rinne 2003] Rinne, Horst: Taschenbuch der Statistik. 3rd Edition. Frankfurt : Verlag Harri Deutsch, 2003

[RWE AG 2006] RWE AG: Konzerngeschäftsbericht 2005. Version: 2006. http: //www.rwe.com/generator.aspx/investor-

relations/finanzberichte/2005/property=Data/id=306416/geschaeftsbericht2005.pdf, Last checked: 15 February 2007

[RWE Trading GmbH 2007] RWE Trading GmbH: Wie der Stromhandel funktioniert - als Mittler zwischen Erzeugung und Vertrieb in einem liberalisierten Strommarkt. Version: February 2007. http://www.rwe.com/generator.aspx/rwe-trading/rwe-trading-microsite/

mediencenter/property=Data/id=416878/stromhandelsmechnismen-download.pdf, Last checked: 15 February 2007

[RWE Transportnetz Strom GmbH 2007] RWE Transportnetz Strom GmbH: Website Ausschreibungen von Regelenergie für RWE Transportnetz Strom. Version: February 2007. https://www2.rwe.com/net/, Last checked: 15 February 2007

[Schröter 2004] Schröter, Jochen: Auswirkungen des Europäischen Emissionshandelssystems auf den Kraftwerkseinsatz in Deutschland, Berlin University of Technology, Institute of Power Engineering, Diplomarbeit, 2004. http://www.basis.gruene.de/bag.energie/papiere/eeg_diplarbeit_schroeter_lang.pdf

[Schwab 2006] Schwab, Adolf J.: Elektroenergie - Erzeugung, Transport, Übertragung und Verteilung elektrischer Energie. Berlin, Heidelberg : Springer-Verlag, 2006

[Stoft 2002] Stoft, Steven ; The Institute of Electrical and Electronics Engineers (Hrsg.): Power Systems Economics: Designing Markets for Electricity. New York : Wiley \& Sons, 2002

[StromNEV 2005] StromNEV: Verordnung über die Entgelte für den Zugang zu Elektrizitätsversorgungsnetzen (Stromnetzentgeltverordnung - StromNEV)/Veröffentlicht am 25. Juli 2005. In: Bundesgesetzblatt, Teil 1, Nr. 46, S. 2225-2242. Version: July 2005. http: //217.160.60.235/BGBL/bgbl1 f/bgbl105s2225.pdf, Last checked: 15 February 2007 
[StromNZV 2005] StromNZV: Verordnung über den Zugang zu Elektrizitätsversorgungsnetzen (Stromnetzzugangsverordnung - StromNZV)/Veröffentlicht am 25. Juli 2005. In: Bundesgesetzblatt, Teil 1, Nr. 46, S. 2243-2251. Version: July 2005. http://217.160.60.235/BGBL/bgbl1f/bgbl105s2243.pdf, Last checked: 15 February 2007

[Swider 2006] Swider, Derk J.: Handel an Regelenergie- und Spotmärkten - Methoden zur Entscheidungsunterstützung für Netz- und Kraftwerksbetreiber. Wiesbaden, IER Stuttgart, Abteilung Energieanwendung und Energiemanagement, Diss., April 2006

[Swider 2005] Swider, Derk J.: Regelenergiemarkt Deutschland - Kosteneffizienz und Perspektiven einer Weiterentwicklung. In: EUROFORUM-Konferenz: Regel- und Ausgleichsenergie. Cologne, August 2005

[Swider and Ellersdorfer 2006] Swider, Derk J. ; Ellersdorfer, Ingo: An Efficient Scoring-Rule to Minimize Strategic Incentives in Multi-Part Procurement Auctions for Power Systems Reserve. Version: June 2006. http://www.ier.uni-stuttgart.de/forschung/projektwebsites/electra/de/PDFDateien/Download_Vortrag_-_IAEE2006.pdf, Last checked: 15 February 2007

[Swider and Weber 2003] Swider, Derk J. ; Weber, Christoph: Ausgestaltung des deutschen Regelenergiemarktes. In: Energiewirtschaftliche Tagesfragen 53 (2003), No. 7, S. 448-453

[UCTE 2004a] UCTE: Appendix 1 - Load-Frequency Control and Performance. Version: June 2004. http://www.ucte.org/pdf/ohb/appendix1_v19.pdf, Last checked: 15 February 2007

[UCTE 2004b] UCTE: Policy 1 - Load-Frequency Control and Performance. Version: July 2004. http://www.ucte.org/pdf/ohb/policy1_v22.pdf, Last checked: 15 February 2007

[UCTE 2007] UCTE: Website of the Union for the Co-ordination of Transmission of Electricity. Version: February 2007. http://www.ucte.org, Last checked: 15 February 2007

[U.S. Department of Justice and the Federal Trade Commission 1997] U.S. Department of Justice and the Federal Trade Commission: Horizontal Merger Guidelines. Version: April 1997. http://www.usdoj.gov/atr/public/guidelines/horiz_book/hmg1.html, Last checked: 15 February 2007

[Vattenfall AB 2006] Vattenfall AB: Annual Report 2005. Version: 2006. http://www.vattenfall.com/www/vf_com/vf_com/Gemeinsame_Inhalte/DOCUMENT/360168vatt/3 86239fina/2005-AnnualReport.pdf, Last checked: 15 February 2007

[Vattenfall Europe Transmission GmbH 2007] Vattenfall Europe Transmission GmbH: Website Ausschreibungen von Regelleistung durch die Vattenfall Europe Transmission GmbH. Version: February 2007. http://www.vattenfall.de/www/trm_de/trm_de/178414ausgl/177385regel/177496aussc/index.jsp, Last checked: 15 February 2007

[VDN 2003a] VDN: Anhang D 1: Unterlagen zur Präqualifikation für die Erbringung von Primärregelleistung für die ÜNB. Version:August 2003. http://www.vdnberlin.de/global/downloads/publikationen/Anhang_D1_PRL.pdf, Last checked: 15 February 2007 
[VDN 2003b] VDN: Anhang D 2: Unterlagen zur Präqualifikation für die Erbringung von Sekundärregelleistung für die ÜNB. Version:August 2003. http://www.vdnberlin.de/global/downloads/publikationen/Anhang_D2_SRL.pdf, Last checked: 15 February 2007

[VDN 2003c] VDN: TransmissionCode 2003 (Netz- und Systemregeln der deutschen

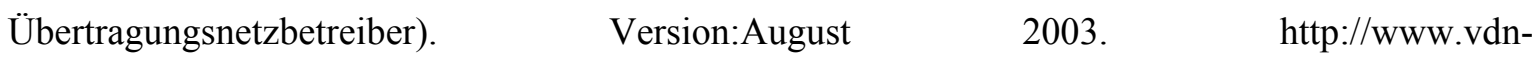
berlin.de/global/downloads/publikationen/TransmissionCode2003.pdf, Last checked: 15 February 2007

[VDN 2006] VDN: Anhang D 3: Unterlagen zur Präqualifikation für die Erbringung von Minutenreserveleistung. Version:August 2006. http://www.vdnberlin.de/global/downloads/publikationen/Anhang_D3_MRL.pdf, Last checked: 15 February 2007

[VDN 2007] VDN: Website des Verbands der Netzbetreiber (VDN). Version: February 2007.http://www.vdn-berlin.de/, Last checked: 15 February 2007 